\title{
Eclampsia: a retrospective study in a tertiary care centre
}

\section{Mohana Dhanapal*, Subha Sivagami Sengodan, Praveena Murugesan}

Department of Obstetrics and Gynecology, Government Mohan Kumaramangalam Medical College Hospital, Salem, Tamil Nadu, India

Received: 09 June 2017

Accepted: 08 July 2017

\section{*Correspondence:}

Dr. Mohana Dhanapal,

E-mail: doctormohana@gmail.com

Copyright: (c) the author(s), publisher and licensee Medip Academy. This is an open-access article distributed under the terms of the Creative Commons Attribution Non-Commercial License, which permits unrestricted non-commercial use, distribution, and reproduction in any medium, provided the original work is properly cited.

\begin{abstract}
Background: This study was done to analyse the maternal mortality, morbidity and fetal outcome in eclampsia complicating pregnancy.

Methods: This study was conducted in Government Mohan Kumaramangalam Medical College and Hospital, Salem. It was a retrospective study from May 2016 to May 2017.

Results: Majority were referral $82.8 \%$. $78.8 \%$ were in the age group of 20-30 years. Primi gravida was the commonest sufferer. In our study $67.02 \%$ had antepartum eclampsia and $31.2 \%$ had postpartum eclampsia. Only $1.8 \%$ patients had intrapartum eclampsia. While taking gestational age majority were preterm. Regarding mode of delivery $61.3 \%$ were delivered by LSCS. $29.2 \%$ of patients had pulmonary edema which was the commonest complication followed by Hellp syndrome (17.7\%), Acute renal failure (10.6\%), Cardiovascular accident $(8.8 \%)$. There were 9 maternal deaths due to eclampsia $(8.3 \%)$. Preterm delivery and Low birth weight were higher in eclamptic patients. Preterm birth occurred in $67.17 \%$ of patients. Intrauterine death occurred in 8 patients. Still birth occurred in $10.6 \%$ of patients.

Conclusions: High maternal morbidity and mortality has been attributed to the late referral, delay in the timely management of preeclampsia. So coordinated efforts of medical and paramedical staffs and health education is needed to fight against eclampsia.
\end{abstract}

Keywords: Eclampsia, Hellp syndrome, Pulmonary edema

\section{INTRODUCTION}

Eclampsia is defined as seizures that cannot be attributed to other causes in women with preeclampsia. Newer onset of grandmal seizures in women with preeclampsia is considered as eclampsia.

Eclampsia remains one of the major causes of maternal mortality and morbidity in developing countries. In developing countries, case fatality ratio is upto $14 \%$ with eclampsia in relation to $1.8 \%$ in developed countries. ${ }^{1}$ In developed countries, incidence of eclampsia is much lower because of aggressive screening and management of preeclampsia. Majority of women who suffered eclampsia associated death had concurrent Hellp syndrome. ${ }^{2}$ Eclampsia is associated with increased rates of maternal complications like abruption placenta, pulmonary edema, Hellp syndrome and acute renal failure Preeclampsia is treatable and eclampsia is preventable. Majority of adverse outcomes can be avoided with proper prediction, timely diagnosis and early management.

\section{METHODS}

This study was conducted in Government Mohan Kumaramangalam Medical College and Hospital Salem. It was a retrospective study from May 2016 to May 2017. 
- Total no of deliveries: 7978

- Total no of eclampsia: 108

All cases were examined, started on magnesium sulphate (Pritchard Regimen) and labetalol. After stabilisation obstetric management was carried out. All antepartum eclampsia patients were terminated irrespective of gestational age.

\section{RESULTS}

The incidence of eclampsia in present study was $1.35 \%$. Majority were referral $82.8 \%$. $78.8 \%$ were in the age group of 20-30 years.

Table 1: Age distribution.

\begin{tabular}{|l|l|}
\hline Age (year) & $\%$ \\
\hline$<20$ & 11.5 \\
\hline $20-30$ & 78.8 \\
\hline $30-40$ & 9.7 \\
\hline
\end{tabular}

Table 2: Parity.

\begin{tabular}{|ll|}
\hline Parity & $\%$ \\
\hline Primi & 71.6 \\
\hline G3 and above & 18.5 \\
\hline
\end{tabular}

Table 2 shows parity distribution in eclamptic patients and primigravida was the commonest sufferer. In our study $67.02 \%$ had antepartum eclampsia and $31.2 \%$ had postpartum eclampsia. Only $1.8 \%$ patients had intrapartum eclampsia. While taking gestational age, majority $67.17 \%$ were preterm. Regarding mode of delivery, $61.3 \%$ were delivered by LSCS and $38.6 \%$ were delivered by vaginal delivery.

Table 3: Type of eclampsia.

\begin{tabular}{|ll|}
\hline Type & $\%$ \\
\hline Antepartum eclampsia & 69.02 \\
\hline Intrapartum eclampsia & 1.8 \\
\hline Postpartum eclampsia & 29.2 \\
\hline
\end{tabular}

Table 4: Gestational age.

\begin{tabular}{|c|c|}
\hline Gestational age & $\%$ \\
\hline$<28$ weeks & 9.07 \\
\hline 28-32 weeks & 17.8 \\
\hline 32-36 weeks & 40.3 \\
\hline 36-40weeks & 32.7 \\
\hline
\end{tabular}

Table 5 shows maternal complications. $29.2 \%$ of patients had pulmonary edema which was the commonest complication followed by Hellp syndrome (17.7\%), Acute renal failure occurred in $10.6 \%$ of patients, Cerebrovascular accident occurred in $8.8 \%$ of patients. There were 9 maternal deaths due to eclampsia (8.3\%).
Preterm delivery and Low birth weight were higher in eclamptic patients. Preterm birth occurred in $67.17 \%$ of patients. Intrauterine death occurred in 8 patients. Still birth occurred in $10.6 \%$ of patients.

Table 5: Complications.

\begin{tabular}{|l|l|}
\hline Complications & $\%$ \\
\hline Abruptio placenta & 5.2 \\
\hline Postpartum haemorrhage & 7.2 \\
\hline DIC & 6.4 \\
\hline HELLP & 17.7 \\
\hline Pulmonary edema & 29.2 \\
\hline Acute renal failure & 10.6 \\
\hline Cerebrovascular accident & 8.8 \\
\hline Posterior reversible encephalopathy syndrome & 7.4 \\
\hline Maternal death & 8.3 \\
\hline
\end{tabular}

\section{DISCUSSION}

Incidence of eclampsia in our study was $1.35 \%$. Majority were in the age group of $20-30$ years $(77.8 \%)$, which is similar to study by Praneet Kaur from Nagpur India. ${ }^{7}$ $71.6 \%$ were primigravidas which is similar to study by Vinaya $\mathrm{G}$ et al $(75 \%){ }^{8}$

Table 6: Incidence of eclampsia.

\begin{tabular}{|ll|}
\hline Study & Incidence \\
\hline${\text { Kuljit Kaur et } \mathrm{al}^{3}}^{\text {Das R et al }}{ }^{4}$ & $1.6 \%$ \\
\hline Sasmita Swain et $\mathrm{al}^{5}$ & $2.67 \%$ \\
\hline Runjun Doley et $\mathrm{al}^{6}$ & $1.39 \%$ \\
\hline Present study & $0.17 \%$ \\
\hline
\end{tabular}

Antepartum eclampsia was the commonest in our study around $69.8 \%$, Which is comparable to study by Anuja Bhalerao et al who reported antepartum eclampsia of $70.91 \% .{ }^{9}$ But postpartum eclampsia was common in study by Chames MC et al because of earlier detection of preeclampsia and prophylactic magnesium sulphate. ${ }^{10}$ $40.3 \%$ of patients were in gestational age of 32-36 weeks. $32.7 \%$ of patients were in gestational age of 36-40 weeks. All patients were stabilised, terminated and delivered within 12 hours. ${ }^{11} 61.3 \%$ of patients were delivered by LSCS.

The main indications for LSCS were unfavourable cervix and failed induction. 5.2\% of eclamptic patients had abruptio placenta which is similar to study by Raji C etal from Tanjore, Tamil Nadu who reported $4.10 \%$ of abruption placentae. ${ }^{12} 7.2 \%$ of patients had postpartum haemorrhage. $6.4 \%$ of patients had DIC which is similar to study by Agrawal $\mathrm{M}$ et al showed $6.97 \%$ of DIC in their study. ${ }^{13}$ Incidence of Hellp syndrome was $17.7 \%$ in our study which is similar to study by Kumari $\mathrm{S}$ et al from Andhra Pradesh who reported 18\% of Hellp syndrome in their study. ${ }^{14} 29.2 \%$ of patients had pulmonary edema in our study. It is the frequent 
complication in our study. Lotha $\mathrm{L}$ reported $33.4 \%$ of pulmonary edema, but Sibai B reported only $2.9 \%$ of pulmonary edema, whereas study Sarkar $\mathrm{M}$ et al reported that pulmonary edema $(72.9 \%)$ was the commonest cause of death in his study. ${ }^{15-17} 10.6 \%$ of patients had Acute renal failure in our study which is similar to study by ET Agida from university of Abuja teaching hospital $(13 \%) .{ }^{18}$ Cerebrovascular accident was $8.8 \%$ in our study whereas in study by Khan A et al reported $40 \%$ of cerebral haemorrhage. ${ }^{19}$ PRES indicative of vasogenic edema occurred in $7.4 \%$ of patients. Maternal mortality in present study was $8.3 \%$.

Table 7: Maternal mortality.

\begin{tabular}{|c|c|}
\hline Study & Maternal mortality (\%) \\
\hline Jido $\mathrm{TA}^{20}$ & 11.7 \\
\hline Pradeep MR et $\mathrm{al}^{21}$ & 0 \\
\hline 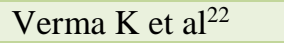 & 6.5 \\
\hline Present study & 8.3 \\
\hline
\end{tabular}

\section{CONCLUSION}

Eclampsia is the leading cause of maternal and fetal mortality. High maternal morbidity and mortality has been attributed to the late referral, delay in the timely management of preeclampsia. So coordinated efforts of medical and para medical staffs and health education is needed to fight against eclampsia.

Funding: No funding sources

Conflict of interest: None declared

Ethical approval: The study was approved by the Institutional Ethics Committee

\section{REFERENCES}

1. Ross MG, Meyer BA, Telavera F, Ramus RM. Eclampsia Overview. Medscape 253960. 2011:1-13.

2. Gracia VD. Maternal deaths due to eclampsia and HELLP syndrome. Internat J Gynecol Obstetrs. 2009;104(2):90-4.

3. Kaur K, Shrivastav RD, Rahatgaonkar V, Bhosale UT. Study of fetal and maternal outcome in eclampsia. Int J Recent Trends Sci Technol. 2014;11:42.

4. Das R, Biswas S. Eclapmsia: the major cause of maternal mortality in eastern india. Ethiopian $\mathrm{J}$ Health Sci. 2015;25(2):111-6.

5. Swain S, Singh S, Das L, Sahoo B. Maternal and perinatal outcome of eclampsia in a tertiary care centre. Internat J Reproduct Contracept Obstet Gynecol. 2016;5(2):384-90.

6. Doley R, Pegu B, Hazarika D. Clinical study of eclampsia in a tertiary care hospital. Ind J Sci Technol. 2016;9(29).

7. Kaur P. A clinical study in eclampsia on a referral hospital. J South Asian Feder Obstet Gynecol. 2012;4(2):113-5
8. Vinaya G, Ahamed SR, Gururaj NG. Incidence of eclampsia and clinical profile: a prospective study. Ind $\mathbf{J}$ Sci Res. 2015;6(2):71.

9. Bhalerao A, Kulkarni S, Ghike S, Kawthalkar A, Joshi S, Somalwar S. Eclampsia: maternal and fetal outcome. JSAFOG. 2013;5(1):19-21.

10. Chames MC, Livingston JC, Ivester TS, Barton JR, Sibai BM. Late postpartum eclampsia: a preventable disease?. Americ J Obstet Gynecol. 2002;186(6):11747.

11. Singh BM, Mishra R. Hypertensivedisorders. Mishra R Editor. Ian Donald's practical obstetric problem. Seventh Edition. BI Publications Pvt Ltd: New Delhi; 2014:142-75.

12. Raji C, Poovathi M, Nithya D. Prospective study of fetomaternal outcome in eclampsia in a tertiary care hospital. International J Reproduct Contracept Obstetr Gynecol. 2016;5(12):4329-34.

13. Praveenkumar AM, Patil R, Pachpande V. Maternal and Fetal Outcome in Eclampsia. Annals Internat Medic Dent Res. 2017;3(2):OG01-OG06.

14. Kumari S, Bhavani, Himabindu P, Padmapriya, Shravya T. Clinical study of Eclampsia and outcome in a tertiary care centre. IOSR-JMDS. 2015;14(11):106-9.

15. Lotha L, Borah A, Lovelin. Maternal and perinatal outcome of eclamptic patients in a tertiary care hospital in Assam. Indian J Appl Res. 2016;6(8):17-19.

16. Sibai BM, Mabie BC, Harvey CJ, Gonzalez AR. Pulmonary edema in severe preeclampsia-eclampsia: analysis of thirty-seven consecutive cases. Am J Obstet Gynecol. 1987;156(5):1174-9.

17. Sarkar M, Basak S, Mondal SK, Das S, Roy D, Mandal J, Mondal SC, Das SK. Maternal mortality associated with eclampsia in an Ind medical college: a four-year retrospective study. J Medic Sci. 2013;4(10):394-8.

18. Agida ET, Adeka BI, Jibril KA. Pregnancy outcome in eclamptics at the University of Abuja Teaching Hospital, Gwagwalada, Abuja: a 3-year review. Nigerian J Clini Pract. 2010;13(4):394-8.

19. Khan A, Ghosh A, Banerjee PK, Mondal TK. Profile and outcome of eclampsia in a rural tertiary hospital. Int J Recent Trends Sci Tech. 2014;10(3):526-9.

20. Jido TA. Ecalmpsia: maternal and fetal outcome. Afr Health Sci. 2012;12(2):148-52.

21. Pradeep MR, Shivanna L. Retrospective study of eclampsia in a teaching hospital. Int $\mathbf{J}$ Recent Trends Sci Technol. 2013;8(3):171-3.

22. Verma K, Baniya GC, Agrawal S, Lomrod S. A study of Maternal and perinatal outcome in eclampsia patients. Indian J Obstet Gynecol Res. 2016;3(4):31821.

Cite this article as: Dhanapal M, Sengodan SS, Murugesan P. Eclampsia: a retrospective study in a tertiary care centre. Int J Reprod Contracept Obstet Gynecol 2017;6:3604-6. 